TITLE:

\title{
Spatial variations in damage zone width along strike-slip faults: An example from active faults in southwest Japan
}

\author{
$\operatorname{AUTHOR}(\mathrm{S}):$ \\ Lin, Aiming; Yamashita, Kazuhiko
}

\section{CITATION:}

Lin, Aiming ...[et al]. Spatial variations in damage zone width along strike-slip faults: An example from active faults in southwest Japan. Journal of Structural Geology 2013, 57: 115

ISSUE DATE:

2013-12

URL:

http://hdl.handle.net/2433/179482

\section{RIGHT:}

@ 2013 Elsevier Ltd.; この論文は出版社版でありません。引用の際には 出版社版をご確認ご利用ください。; This is not the published version. Please cite only the published version. 


\title{
Spatial variations in damage zone width along strike-slip faults: an example from active faults in southwest Japan
}

\author{
Aiming $\operatorname{Lin}^{1 *}$ and Kazuhiko Yamashita ${ }^{2}$ \\ 'Department of Geophysics, Graduate School of Science, \\ Kyoto University, Kyoto 606-8502, Japan \\ ${ }^{2}$ Graduate School of Science and Technology, Shizuoka University, \\ Shizuoka 422-8529, Japan
}

*Corresponding author:

Dr. Aiming LIN

Department of Geophysics, Graduate School of Science

Kyoto University, Kyoto 606-8502, Japan

Tex \& Fax: 81-75-753-3941

E-mail: slin@kugi.kyoto-u.ac.jp

\section{ABSTRACT}

Field investigations reveal spatial variations in fault zone width along strike-slip active faults of the Arima-Takatsuki Tectonic Line (ATTL) and the Rokko-Awaji Fault Zone (RAFZ) of southwest Japan, which together form a left-stepping geometric pattern. The fault zones are composed of damage zones dominated by fractured host rocks, non-foliated and foliated cataclasites, and a fault core zone that consists of cataclastic rocks including fault gouge and fault breccia. The fault damage zones of the ATTL are characterized by subsidiary faults and fractures that are asymmetrically developed on each side of the main fault. The width of the damage zone varies along faults developed within granitic rocks of the ATTL and RAFZ, from $\sim 50$ to $\sim 1000 \mathrm{~m}$. In contrast, the width of the damage zone within rhyolitic tuff on the northwestern side of the ATTL varies from $\sim 30$ to $\sim 100 \mathrm{~m}$. The fault core zone is generally concentrated in a narrow zone of $\sim 0.5$ to $\sim 5 \mathrm{~m}$ in width, consisting mainly of pulverized cataclastic rocks that lack the primary cohesion of the host rocks, including a narrow zone of fault gouge $(<0.5 \mathrm{~m})$ and fault-breccia zones either side of the fault. The present results indicate that spatial variations in the width of damage zone and the asymmetric distribution of damage zones across the studied strike-slip faults are mainly caused by local 
concentrations in compressive stress within an overstep area between left-stepping strike-slip faults of the ATTL and RAFZ. The findings demonstrate that fault zone structures and the spatial distribution in the width of damage zone are strongly affected by the geometric patterns of strike-slip faults.

Keywords: Arima-Takatsuki Tectonic Line, Rokko-Awaji Fault Zone, damage zone, core zone, strike-slip fault, seismic faulting

\section{Introduction}

Active faults and related fault-zone structures that form at shallow depths within the upper crust are closely related to the long-term seismic faulting history of seismogenic faults (e.g., Lin, 1999, 2008; Sibson, 2003; Lin et al., 2010). Accordingly, the analysis of deformation structures along active fault zones provides important information in reconstructing the long-term seismic faulting behavior of active faults and in understanding the tectonic environment and history of such faults.

Active fault zones are generally characterized by damage zones developed on either side of the fault, and an intervening fault core zone that contains the main slip surfaces (Fig. 1) (e.g., Bruhn et al., 1994; Kim et al., 2004; Gudmundsson, 2010; Takagi et al., 2012). The damage zones, which comprise deformed wall rocks that bound the fault core zone, result from the accumulated seismic slip along faults. These zones typically contain fractured host rocks, and foliated and non-foliated cataclasites that retain the primary cohesion of the host rocks. In the case of a mature fault, the width of the damage zone varies from decameters to kilometers (Fig. 1) (e.g., Cowie and Scholz, 1992; McGrath and Davison, 1995; Lin et al., 2007; Takagi et al., 2012).

In contrast, the core zone consists of cataclastic rocks that have lost the primary cohesion of the host rocks, including fault breccia and fault gouge in zones that accommodate the majority of the accumulated seismic slip, which is commonly concentrated in a narrow zone ( $<10 \mathrm{~m}$ wide) along the main fault plane (e.g., Sibson, 1977, 2003; Lin, 1999, 2001; Kim et al., 2004; Mitchell et al., 2011). In a mature fault zone, the damage zone commonly contains subsidiary faults with narrow core zones that include thin zones of fault breccia and fault gouge layers with widths of millimeter to meters. 
This study presents a case study on the structures of strike-slip fault zones of the Arima-Takatsuki Tectonic Line (ATTL) and Rokko-Awaji Fault Zone (RAFZ), which consist of multiple right-lateral strike-slip active faults in southwest Japan. Previous studies have shown that the ATTL and RAFZ are dextral strike-slip active faults (Maruyama and Lin, 2000, 2002, 2004), along which the pulverized fault rocks with numerous ultracataclastic veins are developed (Lin et al., 2001, 2007, 2013; Mitchell et al., 2011). In this study, we focus on the spatial variations in damage zone width and fault zone structures along the ATTL and RAFZ based on field investigations, and discuss the formation mechanisms of damage zone of strike-slip active faults and their tectonic implications.

\section{Geological setting}

The study region is located in the marginal zone of the Eurasia plate, and is bounded by the Median Tectonic Line in southwest Japan (Fig. 2a). The study region contains two major strike-slip active fault zones: the ENE-WSW-striking ATTL and the NE-SW-striking RAFZ, which together form a left-stepping geometric pattern (Figs 2b and 3) (Huzita and Kasama, 1982; Research Group for Active Faults of Japan, 1991; Maruyama and Lin, 2002; Lin et al., 2007). The ATTL is dominated by the Kiyoshikojin, Rokko, and Ibayama faults, which show mainly dextral strike-slip movement. These faults occur along the northern margin of the Osaka Basin, extending for about $60 \mathrm{~km}$ (Figs $2 \mathrm{~b}$ and 3). The average slip rate along the ATTL is 1-3 mm/year horizontally, with a vertical component of $\sim 0.3 \mathrm{~mm} /$ year (Maruyama and Lin, 2002). Based on trench investigations, it is inferred that the youngest seismic faulting event along the fault zone was the M 7.25-7.50 Keicho-Fushimi earthquake of 1596 (Sangawa, 1997; Maruyama and Lin, 2002).

The RAFZ contains the Gosukebashi, Otsuki, Koyo, Suwayama, and Nojima faults, which extend for more than $70 \mathrm{~km}$ from the northeastern part of Awaji Island through the Akashi Strait (where the $1995 \mathrm{M}_{\mathrm{w}} 7.2$ Kobe earthquake occurred; Lin and Uda, 1996), finally meeting the ATTL to the northeast at an oblique angle (Figs $2 \mathrm{~b}$ and 3). Co-seismic surface ruptures produced by the 1995 Kobe earthquake occur mainly along the southern segment of the RAFZ, upon the pre-existing Nojima Fault on Awaji Island (Fig. 2b) (Lin and Uda, 1996). Based on geological structures and analyses of topographical features, it is inferred that (i) the total displacement of the ATTL is 
around $17 \mathrm{~km}$, and (ii) the ATTL and ARFZ formed after mid-Miocene and is presently active, with an average dextral slip rate of $1-3 \mathrm{~mm} / \mathrm{year}$ and a vertical component of 0.3-0.4 mm/year (Maruyama and Lin, 2000, 2002). The penultimate seismic event (i.e., prior to the 1995 Kobe earthquake) upon this fault was the 1596 Keicho-Fushimi earthquake (M 7.25-7.50), as also found along the ATTL (Lin et al., 1998).

The basement rocks in the study region are composed mainly of Cretaceous granitic rocks (Rokko granitic rocks), welded rhyolitic tuff (Arima Group), Oligocene-Eocene sedimentary rocks (Kobe Group), and mid-Pleistocene sedimentary rocks (Osaka Group) (Fig. 3). The Rokko granitic rocks occur mainly on the southwest side of the ATTL, whereas the Arima Group occurs mainly on the northern side. The Kobe Group is dominated by mudstone, sandstone, and conglomerate, and occurs mainly on the northwest side of the ATTL. The Osaka Group comprises weakly consolidated to unconsolidated alternating beds of silt, clay, and gravel, mainly in the southeast part of the study region. Quaternary alluvial deposits are largely restricted to lowland areas in the southeastern part of the study region, on which terrace risers are widely developed (Fig. 3).

\section{Fracture density and occurrence of fault zones}

\subsection{Measurements of fracture density and width of the damage zone}

Damage zones generally consist of weakly deformed host rocks within which fault-related fractures and fault rocks are developed in deformation zones of variable width along the fault. To qualitatively assess the spatial distribution and width of the damage zones and related deformation structures, we first performed field measurements of the fracture density along profiles oriented across fault zones of the ATTL and RAFZ, and then observed the meso- and microstructures of fault rocks developed within the zones. We selected the sides where the basement rocks are well exposed due to strongly erosion of the weak fault damage zone, and measured the fracture density along the profiles across the fault zones. Two typical sites, where the profiles 3-4 are measured, are shown in Fig. 4. Fractures that were visible to the naked eye in the field were counted within an area of $1 \mathrm{~m}^{2}$ using a square frame $(1 \times 1 \mathrm{~m})$ with grid lines at $10-\mathrm{cm}$ intervals. The fractures that intersected each grid line were counted, and the total number of fractures counted in the $1-\mathrm{m}^{2}$ frame was defined as the fracture density. 
The fracture density was measured along six profiles across the ATTL (Profiles 1-6) and three profiles across the Gosukebashi Fault of the RAFZ (Profiles 7-9) (see Fig. 3 for profile locations). The measurement results are plotted as fracture density vs. distance from the fault (Figs 5 and 6), and the inferred damage zones are shown on a topographic map (Fig. 7; for details, see the Discussion). The fracture density varies from $\sim 150 / \mathrm{m}^{2}$ at sites located far from the main fault to $800-900 / \mathrm{m}^{2}$ at sites located close to the main faults, for both the ATTL and RAFZ.

\subsection{Occurrences of the damage zone and the core zone}

The damage zone and the core zone show distinct spatial variations in outcrop-scale deformation structures (Figs 8-10). The basement rocks are strongly fractured and weathered at sites located close to the main fault (Fig. 8a), and the fracture density shows a gradual decrease away from the main fault (Fig. 8b-d), as indicated by the measurement. In both the ATTL and RAFZ, the core zones are generally $<10 \mathrm{~m}$ in width and are bounded by the damage zones on either side of the main fault, which are composed of pulverized fault rocks, including fault gouge and fault breccia, which have lost the primary cohesion of the host rocks. Figures 9 and 10 show typical outcrops of faults, illustrating the field occurrences of the damage zone and the core zone of the ATTL (Loc. 1) and RAFZ (Loc. 2), respectively. These features are described in detail below.

A fault within the ATTL is exposed at a contact between granitic rocks and rhyolitic tuff of the Arima Group (Fig. 3), revealing the fault core zone and the damage zone (Fig. 9). The core zone (fault gouge and breccia) is $\sim 5 \mathrm{~m}$ wide, bounded by two distinguishable fault planes (F1 and F2) marked by brown, black, and gray layers of fault gouge in a zone of 10-20 cm wide (Fig. 8). The boundaries between layers of fault gouge of varying color are generally sharp but locally irregular. Both of the main fault

160 planes strike ENE-WSW and dip to the SSE at $\sim 80^{\circ}$. Striations on the main fault planes

161 plunge ENE at $5-10^{\circ}$, indicating that the ATTL has a predominantly strike-slip 162 component (Fig. 9). The fault gouge zones along the F1 and F2 faults are bounded by 163 breccia zones ( $\sim 5 \mathrm{~m}$ wide), which comprise fragments of granitic rocks and rhyolitic 164 tuff of various sizes (Fig. 9). 
Damage zones, which are developed on both sides of the core zone, consist of foliated and non-foliated cataclasites that originated from granitic rocks and rhyolitic tuff on the northeast and southwest sides of the fault, respectively (Fig. 9). The boundaries between the damage zones and the core zones are generally sharp and are easily recognized in the field. The fault breccia zones are bounded by foliated cataclasite zones (3-5 m wide) on both sides of the core zone. The foliated cataclasite zones are bounded in turn by non-foliated cataclasite zones (>100 m wide). The boundary between the foliated cataclasite and non-foliated cataclasite is generally gradational. Previous study has reported that the width of damage zone at Loc.1 is 200 $\mathrm{m}$ with a core zone including a breccia zone of $\sim 2 \mathrm{~m}$ and fault gouge zone of $8-10 \mathrm{~cm}$ in width (Mitchel et al., 2011), which are comparable with that measured quantitatively in this study as stated above.

The Gosukebashi Fault is developed in granitic rocks (Fig. 3), and the core zone is bounded by damage zones on either side of the fault (Fig. 10). The core zone is composed of fault gouge and fault breccia, in a zone of 1-1.5 m wide. The fault gouge consists of layers of different colors, as also observed at Loc. 1, within a zone of 20-50 $\mathrm{cm}$ wide. The damage zone comprises foliated cataclasite that bounds the fault gouge on the northwest side of the fault, and non-foliated cataclasite on the southeast side (Fig. 10). The boundaries between the foliated cataclasite and the fault gouge zone, and between the non-foliated cataclasite and the fault breccia zone are generally sharp and easily recognized in the field. The foliated cataclasite at this location occurs within a zone of $\sim 5 \mathrm{~m}$ wide. The foliated cataclasite contains an asymmetric fabric of aggregates of rock fragments, as observed in a polished $\mathrm{X}-\mathrm{Z}$ section (i.e., perpendicular to the fault plane and parallel to striations), indicating dextral displacement, consistent with the displacement inferred from offset terrace risers and gullies (Lin, 1999).

\section{Meso- and microstructures}

\subsection{Mesostructures}

To document the structural features of the fault rocks in the damage zone and in the core zone, we examined polished sections cut from hand samples. For the fault gouge zone at Loc. 1, we analyzed an $\mathrm{X}-\mathrm{Z}$ section (i.e., perpendicular to the fault plane 
and parallel to striations). Figures 11 and 12 show typical polished sections of the various fault rocks.

The structural features of the core zone and the damage zone were observed in the polished sections. The fault core zone is composed of non-cohesive fault gouge and fault breccia, in which the primary fabrics of the host rocks are unrecognizable (Fig. $11 \mathrm{a}-\mathrm{c})$. The fault gouge zone consists of three thin layers of contrasting color (brown, black, and gray), as observed in the field, and is characterized by asymmetric fabrics (Fig. 11a and b) that indicate dextral displacement, consistent with the displacement inferred from offset terrace risers and gullies (Maruyama and Lin, 2002). The fault breccia zone consists mainly of angular to sub-angular fragments of various sizes (sub-micron to $1 \mathrm{~cm}$ ), and shows a random fabric (Fig. 11c).

The damage zone consists of cataclasite and weakly deformed host rocks. The cataclasite is observed in a narrow zone located $<17 \mathrm{~m}$ from the main fault plane, within rhyolitic tuff on the northwest side of the ATTL (Fig. 11d and e). In contrast, the cataclasite is observed throughout a wide zone (up to $400 \mathrm{~m}$ ) within granitic rocks on the southeast side of the ATTL (Fig. 12). At $<100 \mathrm{~m}$ from the main fault, the damage zone is strongly fractured and partially brecciated, and is generally weathered and soft (Fig. 12a-c). In contrast, the damage zone at 100-300 $\mathrm{m}$ from the main fault is a typical cataclasite, without any apparent brecciation. Compared with the host granitic rocks, the damage zone located at 400-600 $\mathrm{m}$ from the main fault (Fig. 12f-h) contains a higher density of fractures and microcracks. These observations by the naked eye indicate that structural variations within the damage zones are strongly controlled by faulting along the main faults.

\subsection{Microstructures}

Microstructurally, distinct spatial variations are apparent in the structural features of the core zone and the damage zone, as also observed in the field and in polished sections (see above). The fault gouge zone consists mainly of super-fine to fine-grained matrix and fragments, characterized by microcracks filled by calcite and showing asymmetric fabrics (Fig. 13a and b). Some calcite veins are dextrally offset along microcracks oriented parallel to the main fault (as also observed in an $\mathrm{X}-\mathrm{Z}$ thin section; Fig. 13a). The asymmetric fabrics and offset calcite veins indicate dextral movement upon the fault, consistent with the displacement inferred from polished sections of hand 
231 samples (see above). The fault breccia zone is characterized by angular to sub-angular microbreccia clasts of various sizes (sub-micron to millimeters) in a fine-grained matrix (Fig. 13b).

The damage zones are characterized by foliational fabrics, numerous microcracks, and microbreccias (Fig. 13c-f). The foliational fabrics are observed in the foliated cataclasites, which are characterized by variable color, visible cracks, and the preferred orientation of asymmetric aggregates of rock fragments (Fig. 13c).

The foliational fabrics indicate a predominately dextral strike-slip movement upon the Gosukebashi Fault (Lin, 1999). The non-foliated cataclasite and fractured host rocks have a random fabric, with microbreccia clasts ranging in size from several tens to hundreds of microns (Fig. 13d-f). The microcracks are generally filled by fine-grained angular to sub-angular fragments of granitic rocks. The damage zone contains cataclasite at up to $\sim 300 \mathrm{~m}$ from the main fault (Fig. 13b-g); at $>400 \mathrm{~m}$ from the main fault, the granitic rocks are only affected by micro-fractures (Fig. 13h).

The observed microstructures indicate that (i) the cataclasite is developed in a wide zone ( $\sim 300 \mathrm{~m})$ and (ii) the damage zone is $>\sim 400 \mathrm{~m}$ wide, consistent with field observations and the measured fracture density.

\section{Discussion}

\subsection{Width of the damage zone}

The width of a brittle fault zone has been widely used as an important parameter in estimating fault length, total displacement, and in understanding the tectonic history of fault activity (e.g., Sibson, 1977, 2003, Scholz, 1987; Cowie and Scholz, 1992; Chester and Chester, 1998; Takagi et al., 2012). Brittle fault zones are generally characterized by damage-zone structures that are subsidiary to the fault core zone, including localized cataclasites, subsidiary faults, and fractures within the weakly deformed protolith (e.g., Chester et al., 1993; Lin et al., 2007). The fault core zone is generally the zone of strongest deformation, along which most of the strain energy associated with seismic faulting is released. Subsidiary faults are often developed within mature brittle fault zones, along which fault gouge and breccia zones formed along the fault planes, such as the Nojima Fault Zone which triggered the 1995 Kobe $_{\mathrm{w}} 7.2$ earthquake (Lin et al., 2001) and the Carboneras Fault Zone (Spain) (Rutter et al., 2012). The F1 and F2 faults observed at Loc. 1 are considered as such subsidiary faults along 
which the fault gouge and breccia zone formed (Fig. 9). The variable colors of fault gouges developed along the main faults probably reflect oxidation and the presence of alternating layers of mafic minerals and weathered material that has been affected by underground water that flowed through the fault zone at shallow depths. Such color layering structures of fault gouge have been reported in some active fault zones, such as the Nojima Fault (Japan) (Lin et al., 2001) and the Chelungpu Fault (Taiwan) which triggered the $1999 \mathrm{M}_{\mathrm{w}}$ 7.6 Chi-Chi earthquake (Lin et al., 2005; Lin, 2008). The width of damage zone is typically affected by the seismic faulting that occurs on the main fault planes, and record a much smaller bulk shear strain than the core zone (e.g., Caine et al., 1996; Lin et al., 2007, 2010). Previous studies have reported a close relationship between the amount of accumulated fault slip and the thickness of the core zone (e.g., Scholz, 2002; Mitchell and Faulkner, 2009), and that the damage zones have heterogeneous mechanical properties due to variations in fracture density (e.g., Gudmundsson et al., 2010).

The fracture-density data shown in Figs 5 and 6 reveal that (i) the fracture density decreases from $600-900 / \mathrm{m}^{2}$ (in measured values) in the areas around the main faults, to $150-200 / \mathrm{m}^{2}$ within the host rocks at sites located far from the main faults; and (ii) the width of the zone of high fracture density varies along the fault, from a narrow zone of 50-100 $\mathrm{m}$ in the southwest segment of the ATTL and the Gosukebashi Fault of the RAFZ to a wide zone of up to $>1200 \mathrm{~m}$ on the east side of the fault, where the two fault zones are merged (Figs 5 and 6). In all profiles, the fracture density is between $\sim 150$ and $\sim 200 / \mathrm{m}^{2}$ within the undeformed granitic host rock at 100-1000 $\mathrm{m}$ from the main faults of the ATTL and RAFZ (Figs 5 and 6). This narrow range probably reflects the background fractures that were generated mainly in response to regional tectonic stress or primary joints that formed in those parts of the host rocks that are not directly affected by faulting within the fault zones of the ATTL and RAFZ. Therefore, the zones with a high fracture density $\left(>\sim 200 / \mathrm{m}^{2}\right)$ are considered to be fault damage zones that are strongly affected by displacement along the fault zones of the ATTL and RAFZ (Figs 5 and 6). Our results are comparable with that reported by Mitchell et al. (2011) in which the damage zone of ATTL is estimated to be $\sim 500 \mathrm{~m}$ in width.

Previous studies have shown that the damage zones along the southern segment of the Kosukebashi Fault (Lin, 1999) and along the Nojima Fault are $\sim 50$ m wide (Lin et al., 2007). The present results, combined with these previous findings, indicate that the 
297 damage zones vary in width from $\sim 50 \mathrm{~m}$ along the faults to $\sim 2000 \mathrm{~m}$ in the area where 298 the ATTL joins the RAFZ (Fig. 7).

\subsection{Tectonic implications}

Inclined faults commonly show an asymmetric strain pattern around the fault core zone, which justifies the proposed separation of the damage zone into distinct damage domains (Berg and Skar, 2005). The asymmetric fracture pattern within damage zones along mature faults has been related to: (i) geometric controls, (ii) variations in the stress field during faulting, (iii) contrasting rock properties across the fault, and (iv) the growth process of the fault zone (e.g., Mandl, 2000; Berg and Skar, 2005).

The strike-slip faults of the ATTL and RAFZ also show an asymmetric deformation pattern in the damage zones (Figs 5 and 6). The damage zones along the Gosukebashi Fault of the RAFZ and on the southern side of the Rokko and Ibayama faults of the ATTL are all developed within the Rokko granitic rocks, indicating that spatial variations in the width of the damage zone along these faults are not caused by variations in the lithological properties along the faults. At the western end of the Ibayama Fault, damage zones within rhyolitic tuff on either side of the fault have a similar width (50-100 m; Profile-1 in Fig. 5). This finding indicates no distinct difference in rock properties within the rhyolitic rocks across the faults of the ATTL. In addition, there is no distinct difference in the growth process of fault zones along the strike-slip faults of the ATTL and RAFZ. Therefore, mechanisms (iii) and (iv) listed above had little influence on the development of spatial variations in the width of the damage zone along these faults.

In fact, the local stress field (mechanism (ii) above) is the main controlling factor of fracture propagation and arrest, along with associated seismic events along the faults (e.g., Gudmundsson et al., 2010). The local stresses along fault zones are strongly associated with geometric irregularities along the faults (mechanism (iii) above; e.g., Gabrielsen et al., 1998). Upon en echelon strike-slip faults, the local stresses are generally concentrated in the jog (or overstep) areas, where compressional or extensional (dilatational) stresses develop (Scholz, 2002). The presence of a jog within a fault zone may impede or terminate dynamic rupture, and in some cases may control rupture initiation (Sibson, 1986; Harris and Day, 1999). Seismic slip transfer across a compressional jog is further impeded by the enhanced compressive stress on the linking 
330 faults or within the intervening region (Scholz, 2002). The fault zones of the ATTL and

331 RAFZ show a left-stepping geometric pattern; therefore, a jog (overstep) forms a

332 contractional area in which compressional stress is concentrated (Fig. 14). Because of

333 the synthetic movement upon the faults on both sides of the jog, a contractional

334 environment forms around the overstep area. Previous studies have reported that the

335 formation of the ATTL and RAFZ was probably related to the opening of the Japan Sea,

336 which is the dominant tectonic event around Japan since mid-Miocene (Maruyama and

337 Lin, 2000, 2002). Accordingly, the wide damage zones observed in this overstep area

338 are considered to be caused by the compressive stress generated since mid-Miocene in

339 the left-stepping jog area between the strike-slip faults of the ATTL and of the RAFZ.

\section{Conclusions}

Based on the results presented above, we make the following conclusions regarding spatial variations in the width of the fault damage zone along the ATTL and along the RAFZ.

1. The width of the damage zone varies from 50 to $1000 \mathrm{~m}$ along the active faults of the ATTL and the RAFZ.

2. The damage zones are asymmetrically distributed on each side of faults within the overstep area of left-stepping strike-slip faults of the ATTL and RAFZ.

3. The results demonstrate that fault zone structures and the spatial distribution in the width of damage zone are strongly influenced by the geometric patterns of strike-slip faults.

\section{Acknowledgements}

We would like to thank Professor J. White and an anonymous reviewer for their critical reviews and Professor C. Passchier for editorial comments that helped to improve the manuscript. We are also grateful to T. Maruyama and M. Tanaka for their assistance in the field, and to $\mathrm{S}$. Takano for XRD analysis. This work was supported by Grand-in-Aid Scientific Research (A) (Science Project No. 23253002 for A. Lin) of the Ministry of Education, Culture, Sports, Science and Technology of Japan

\section{References}

362 Berg, S.S., Skar, T., 2005. Controls on damage zone asymmetry of a normal fault zone: 
outcrop analyses of a segment of the Moab fault, SE Utah. Journal of Structural Geology 27, 1803-1822.

Bruhn, R.L., Perry, W.T., Yonkee, W.A., Thompson, T., 1994. Fracturing and hydrothermal alternation in normal fault zones. Pure and Applied Geophysics 142, $609-644$.

Caine, J.S., Evans, J.P., Poster, C.B., 1996. Fault architecture and permeability structure. Geology 24, 1025-1028.

Cowie, P.A., Scholz, C.H., 1992. Physical explanation for the displacement-length relationship of faults, using a post-yield fracture mechanics model. Journal of Structural Geology 14, 1133-1148.

Chester, F.M., Chester, J.S., 1998. Ultracataclasite structure and friction processes of the Punchbowl Fault, San Andreas system, California. Tectonophysics 295, 199-221.

Chester, F.M., Evans, J.P., Biegel, R., 1993. Internal structures and weakening mechanisms of the San Andreas fault. Journal of Geophysical Research 98, $771-786$.

Gabrielsen, R.H., Aarland, R.-K., Alasler, E., 1998. Identification and spatial distribution of fractures in porous, siliclastic sediments. In: Stephansson, B. (Ed.), Rock Joints, Balkema, Rotterdam, pp. 45-50.

Gudmundsson, A., Simmenes, T.H., Belinda, L., Philipp, S.L., 2010. Effects of internal structure and local stresses on fracture propagation, deflection, and arrest in fault zones. Journal of Structural Geology 32, 1643-1655, doi:10.1016/j.jsg.2009.08.013.

Harris, R. A., Day, S.M., 1999. Dynamic 3D simulations of earthquakes on en echelon faults. Geophysical Research Letters, 26, 2089-2092.

Huzita, K., Kasama, T., 1982. Geology of the Osaka-Seihokubu district. Quadrangle series, 1:50,000, Geological Survey of Japan, 112 pp. (in Japanese with English abstract).

Kim, Y.-S., Peacock, D.C.P., Sanderson, D.J., 2004. Fault damage zones. Journal of Structural Geology 26, 503-517.

Lin, A., 1999. S-C cataclasite in granitic rocks. Tectonophysics 304, 257-273.

Lin, A., 2001. S-C fabrics developed in cataclastic rocks from the Nojima fault zone, Japan and their implications for tectonic history. Journal of Structural Geology 23, 
$1,167-1,178$.

Lin, A., 2008. Fossil earthquakes: the formation and preservation of pseudotachylytes. Springer, Berlin, 348pp (ISBN 978-3-540-74235-7).

Lin, A., Uda, S., 1996. Morphological characteristics of the earthquake surface ruptures occurred on Awaji Island, associated with the 1995 Southern Hyogo Prefecture Earthquake. The Island Arc 5, 1-15.

Lin, A., Maruyama, T., Miyata, T., 1998. Paleoseismic events and the 1596

Keicho-Fushimi large earthquake produced by a slip on the Gosukebashi fault at the eastern Rokko Mountains, Japan. The Island Arc 7, 621-636.

Lin, A., Shimamoto, T., Maruyama, T., Sigetomi, M., Miyata, T., Takemura, K., Tanaka, H., Uda, S., Murata, A., 2001. Comparative study of cataclastic rocks from a drill core and outcrops of the Nojima Fault zone on Awaji Island, Japan. Island Arc 10, 368-380.

Lin, A., Lee, C-T., Maruyama, T., Chen, A., 2005. Meso- and microstructural analysis of coseismic shear zone of the Mw 7.6 Chi-Chi earthquake, Taiwan. Bulletin of Seismological Society of America 95, 486-501.

Lin, A., Ren, Z., Kumahara, Y., 2010. Structural analysis of the coseismic shear zone of the $2008 \mathrm{M}_{\mathrm{w}}$ 7.9 Wenchuan earthquake, China. Journal of Structural Geology 32, 781-791.

Lin, A., Maruyama, T., Kobayashi, K., 2007, Tectonic implications of damage zone-related fault-fracture networks revealed in drill core through the Nojima fault, Japan. Tectonophysics 443, 161-173.

Lin, A., Yamashita, K., Tanaka, M., 2013. Repeated seismic slips recorded in ultracataclastic veins along active faults of the Arima-Takatsuki Tectonic Line, southwestern Japan. Journal of Structural Geology 48, 3-13.

Maruyama, T., Lin, A., 2000. Tectonic history of the Rokko active fault zone (southwest Japan) as inferred from cumulative offsets of stream channels and basement rocks. Tectonophysics 343, 197-216.

Maruyama, T., Lin, A., 2002. Active strike-slip faulting history inferred from offsets of topographic features and basement rocks: a study of the Arima-Takatsuki Tectonic Line, southwest Japan. Tectonophysics 344, 81-101.

Maruyama, T., Lin, A., 2004. Slip sense inversion on active strike-slip active faults in the southwestern Japan, and its implications for Cenozoic tectonic evolution. 
Tectonophysics 383, 45-70.

Mandl, G., 2000. Faulting in brittle rocks. In introduction to the mechanics of tectonics. Springer, Berlin.

McGrath, A.G., Davison, I., 1995. Damage zone geometry around fault tips. Journal of Structural Geology 17, 1011-1024.

Mitchell, T.M., Faulkner, D.R., 2009. The nature and origin of off-fault damage surrounding strike-slip fault zones with a wide range of displacements: A field study from the Atacama fault system, northern Chile. Journal of Structural Geology 31, 802-816.

Mitchell, T.M., Ben-Zion, Y., Shimamoto, T., 2011. Pulverized fault rocks and damage asymmetry along the Arima-Takatsuki Tectonic Line, Japan. Earth and Planetary Science Letters 308, 284-297.

Research Group for Active Faults of Japan, 1980. Active faults in Japan-Sheet maps and inventories. Univ. Tokyo Press, Tokyo, 363pp (in Japanese with English summary).

Rutter, E.R., Faulkner, D.R., Burgess, R., 2012. Structure and geological history of the Carboneras Fault Zone, SE Spain: Part of a stretching transform fault system. Journal of Structural Geology 45, 68-86.

Sangawa, A., 1997. Moving earth: earthquakes in Japan. Dohosha Ltd., Kyoto, 272 pp. (in Japanese).

Scholz, C.H., 1987. Wear and gouge formation in brittle faulting. Geology 15, 493-495.

Scholz, C.H., 2002. The mechanics of earthquake and faulting, Cambridge University Press, New York, 471pp.

Sibson, R. H., 1977. Fault rocks and fault mechanisms. Journal of Geological Society of London 133, 191-213.

Sibson, R.H., 1986. Rupture interaction with fault jogs. In Earthquake Source Mechanics. AGU Geophys. Mono. 37, S. Das, J. Boatwright, and C. Scholz (Ed.). Washiton, D.C., American Geophysical Union, pp.157-168.

Sibson, R.H., 2003. Thickness of the seismic slip zone. Bulletin of Seismological Society of America 93, 1169-1178.

Takagi, H., Takahashi, K., Shimada, K., Tsutsui, K., Miura, R., Kato, N., Takizawa, S., 2012. Integrated estimates of the thickness of the fault damage zone in granitic terrain based on penetrative mesocracks and XRD analyses of quartz. Journal of 


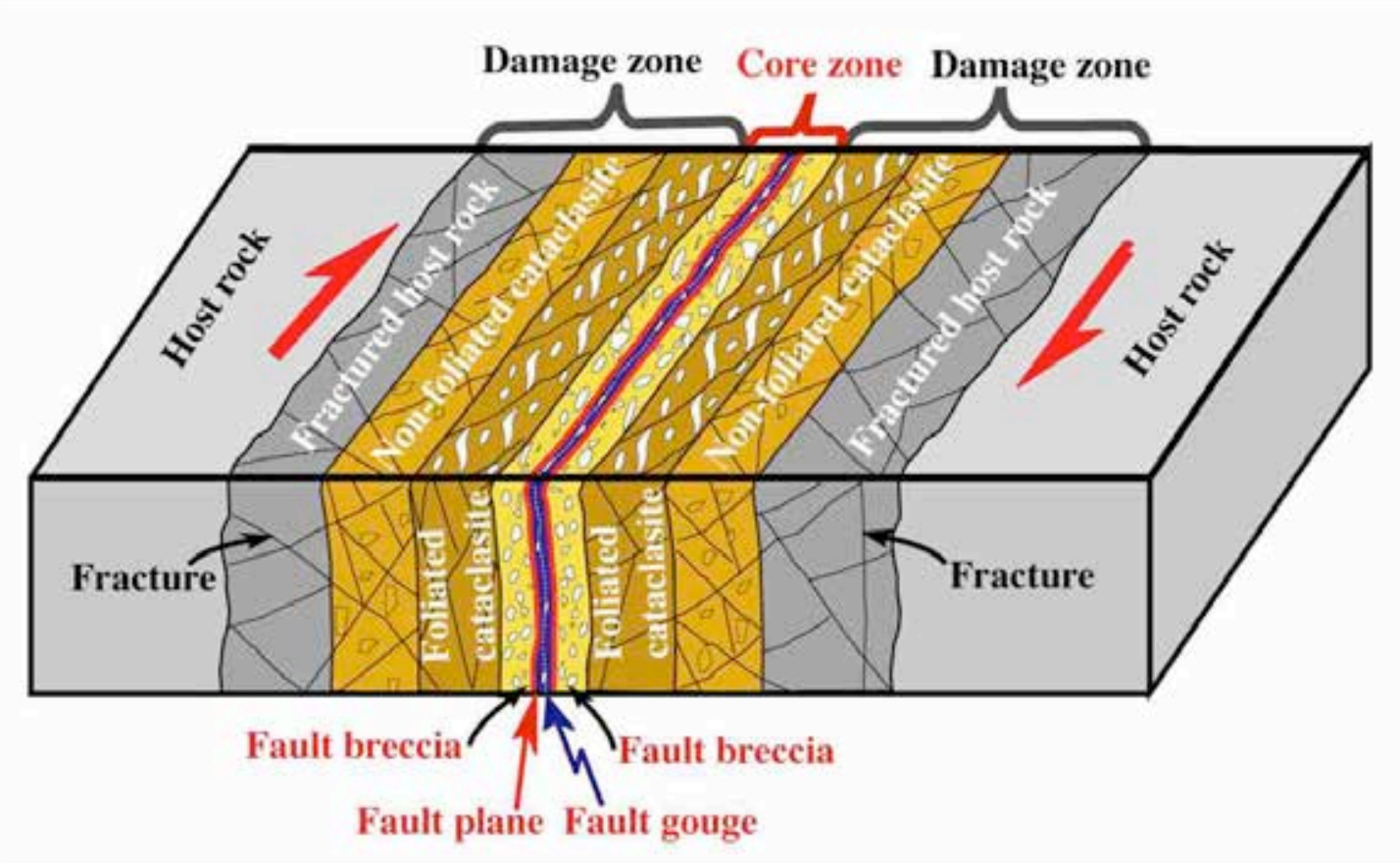

Figure 1. Schematic model of a fault core zone and damage zone within a strike-slip fault zone. The fault core zone consists of fault breccia and fault gouge that have lost the primary cohesion of the host rocks. The damage zone is composed of foliated and non-foliated cataclasites and fractured host rocks that retain the primary cohesion of the host rocks. Red arrows indicate the sense of strike-slip displacement on the fault. 


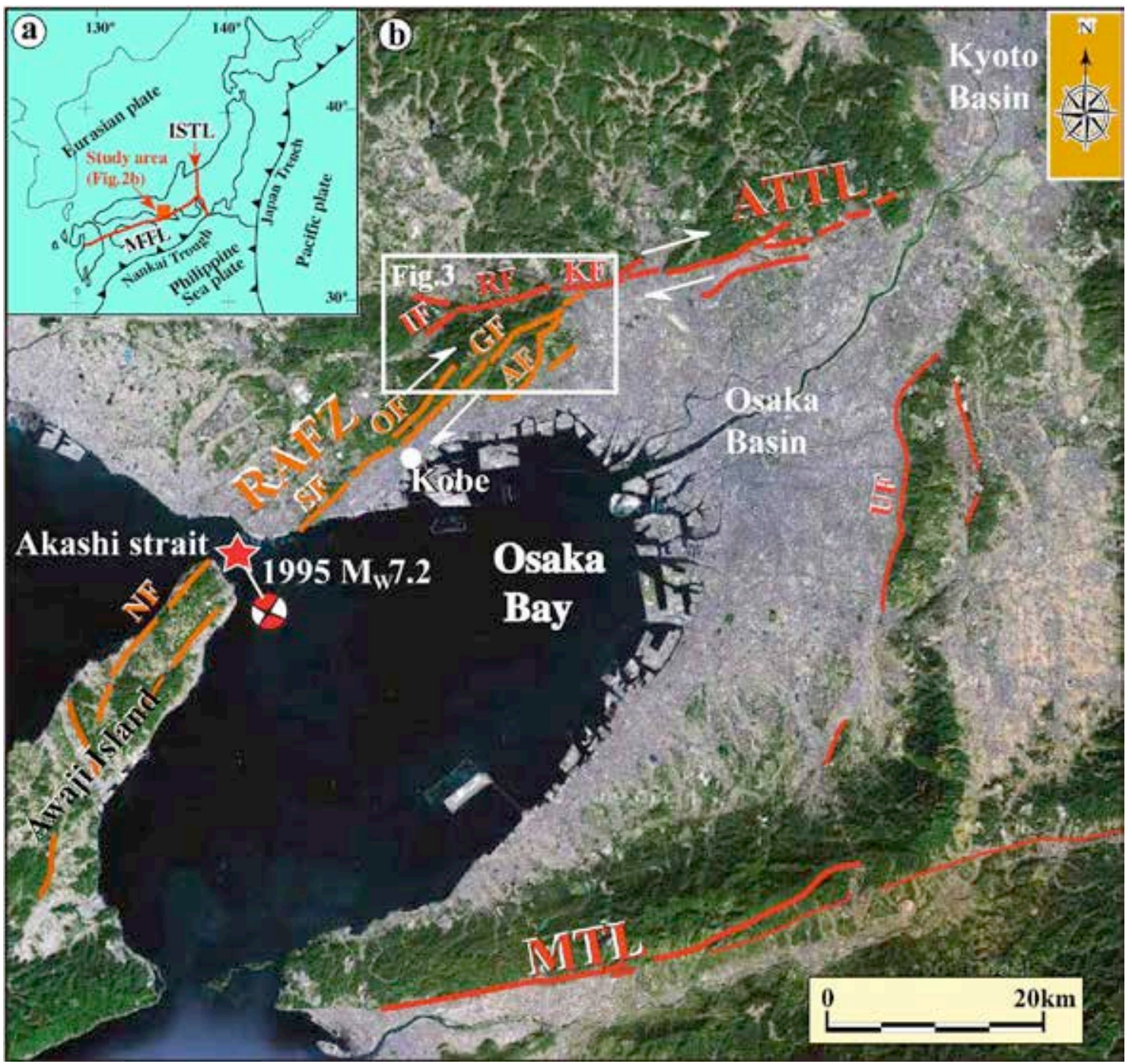

Figure 2. Index maps of the study region, showing the distribution of active faults of the Arima-Takatsuki Tectonic Line (ATTL) and Rokko-Awaji Fault Zone (RAFZ). (a) Index map showing the tectonic setting of Japan. MTL: Median Tectonic Line; ISTL: Itoigawa-Shizuoka Tectonic Line. (b) Google image showing the distribution of active faults of the ATTL and RAFZ. Red star indicates the location of the $1995 \mathrm{M}_{\mathrm{w}} 7.2$ Kobe earthquake. KF: Kiyoshikojin Fault; RF: Rokko Fault; IF: Ibayama Fault; GF: Gosukebashi Fault; AF: Ashiya Fault; OF: Otsuki Fault; SF: Suwayama Fault; NF:

478 Nojima Fault; UF: Uemachi Fault. White arrows indicate the movement sense upon 479 faults. 


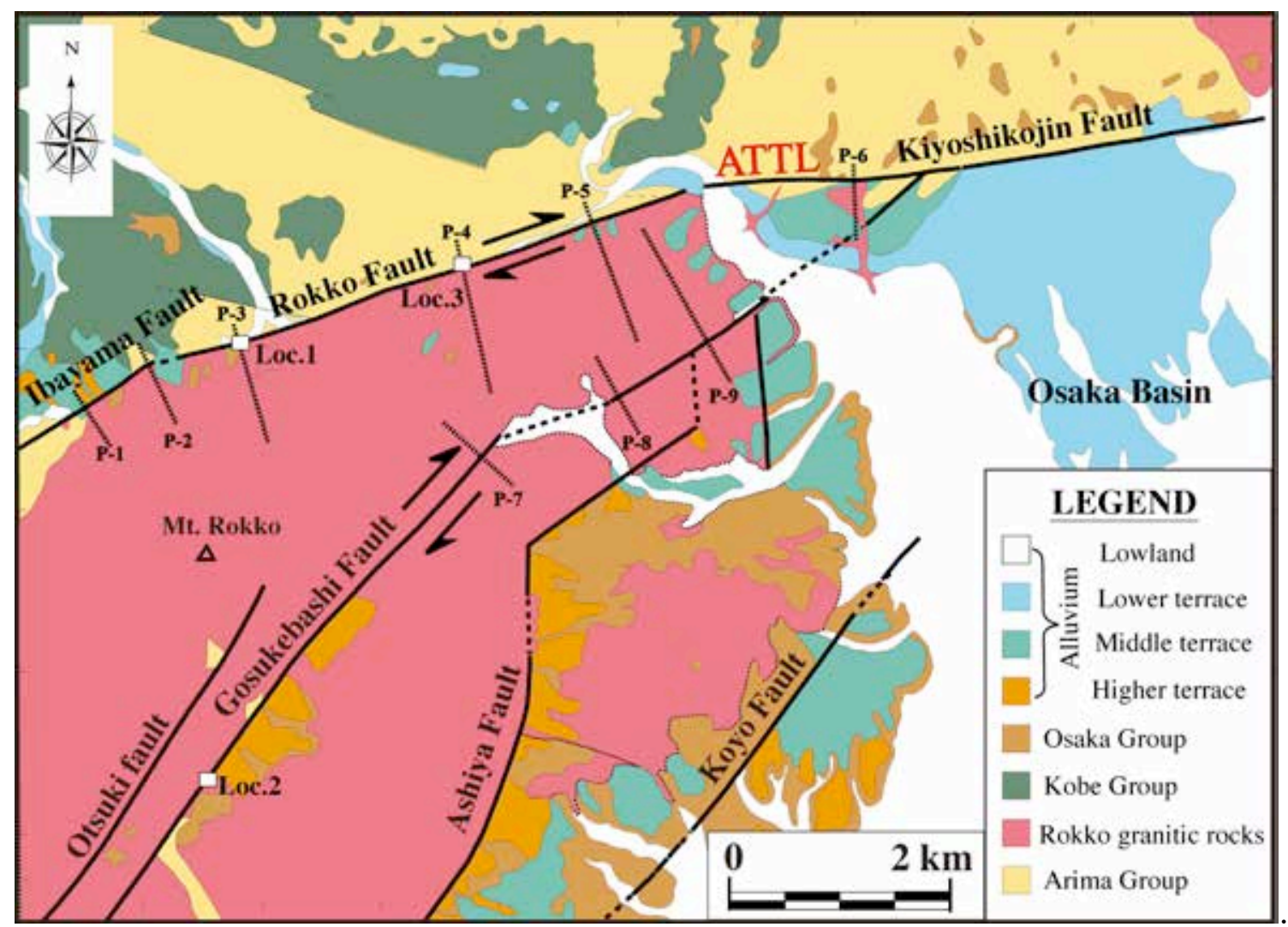

482

Figure 3. Geological map of the study region (modified from Huzita and Kasama, 1982).

P1-P9 (dashed lines) indicate profiles along which the fracture density was measured. 

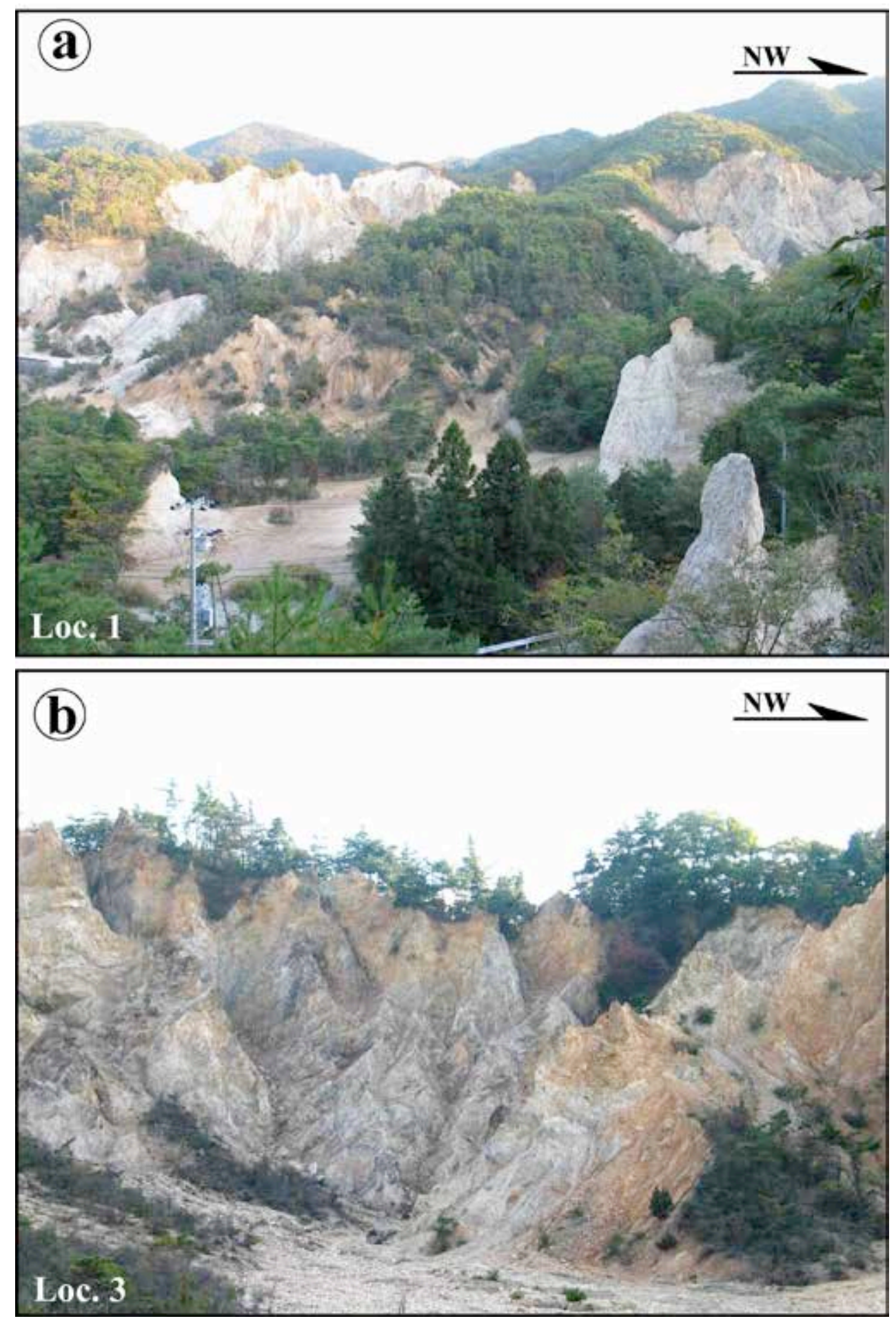

Figure 4. Photographs of outcrops at Loc. 1 (a) and Loc. 3 (b). Note that granitic rocks are strongly weathered and eroded along the Rokko Fault. See Figure 3 for detail locations of Locs. 1 and 3 where the photos were taken. 

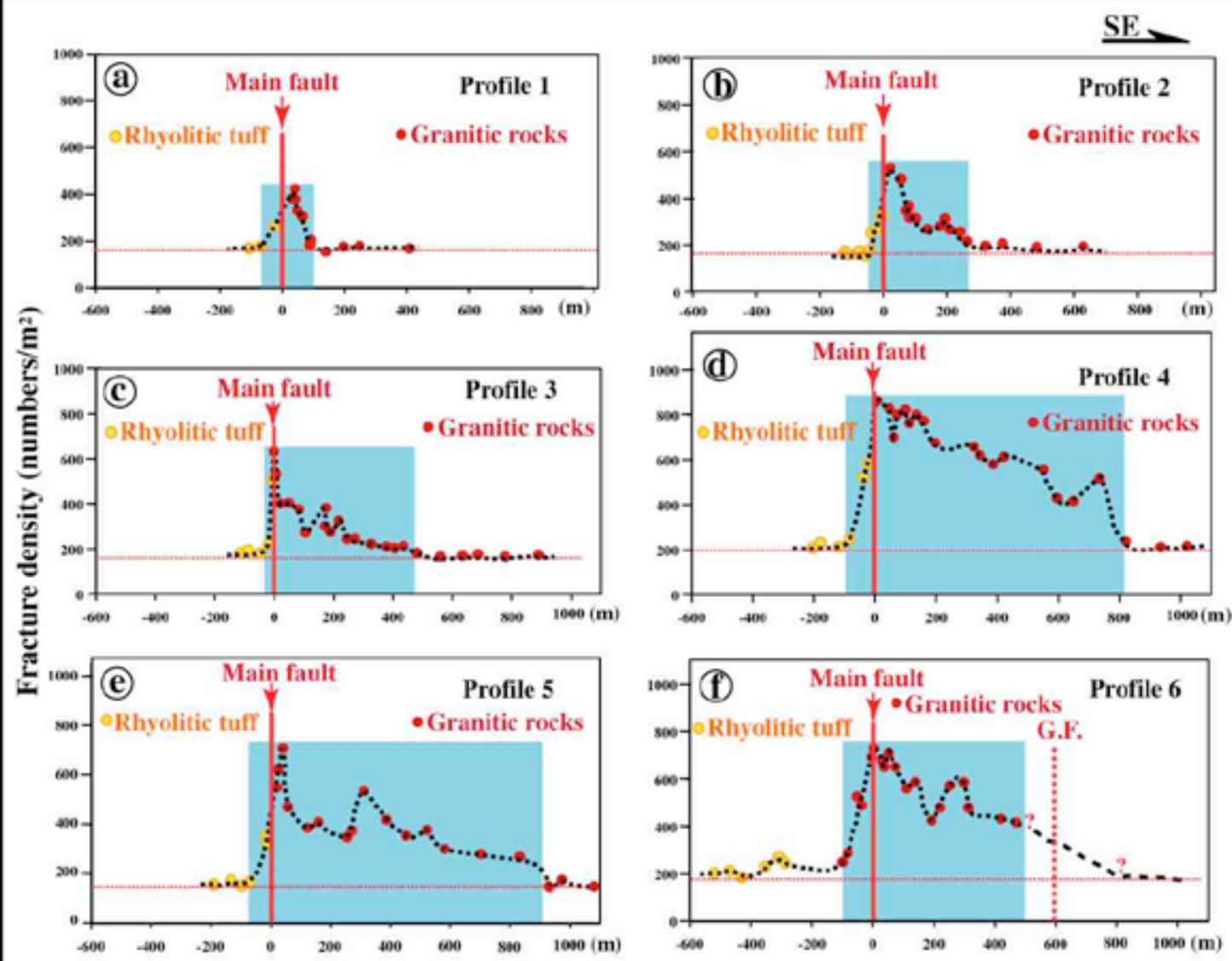

Distance from the main fault (ATTL)

Figure 5. Spatial variations in fracture density with increasing distance from the main faults of the ATTL. (a)-(f) show Profiles 1-6, respectively. Basement rocks are not exposed on the southeast side of Profile 6. G.F.: Gosukebashi Fault. Profiles 1-2, Profiles 3-5, and Profile 6 are set across the Ibayama, Rokko, and Kiyoshikojin faults, respectively. See Figure 3 for the locations of the profiles. Blue areas indicate that part of the damage zone with a higher fracture density than the background density in the host rocks (indicated by a red dotted line). 


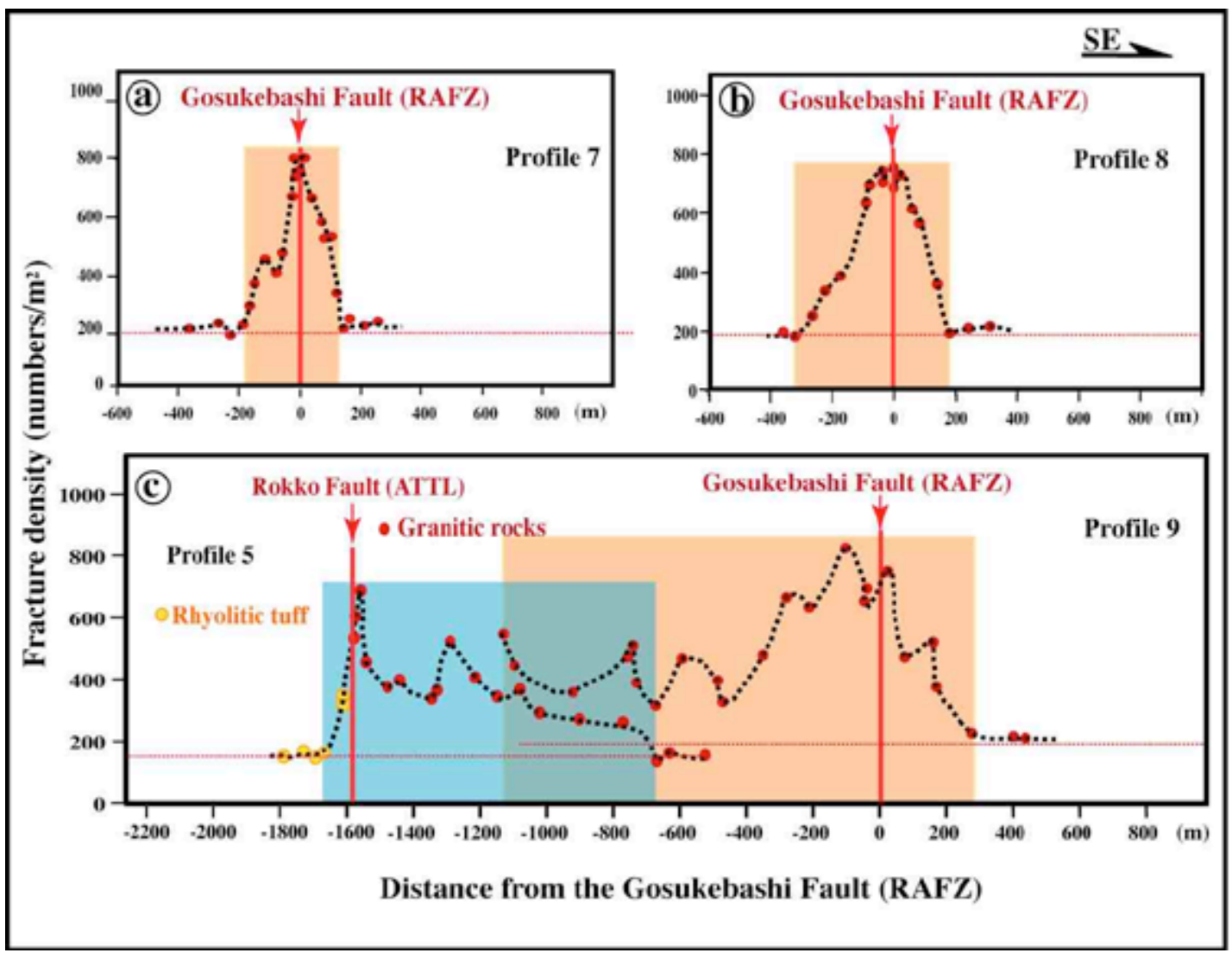

Figure 6. Spatial variations in fracture density with increasing distance from the

Gosukabashi Fault of the RAFZ. (a)-(c) show Profiles 7-9, respectively. Profile 5 across the Rokko Fault is also shown here, as an extension of Profile 9. See Figure 3 for the locations of the profiles. Orange areas indicate that part of the damage zone with a higher fracture density than the background density in the host rocks (indicated by a red dotted line). Blue area indicates the damage zone in Profile 5. 


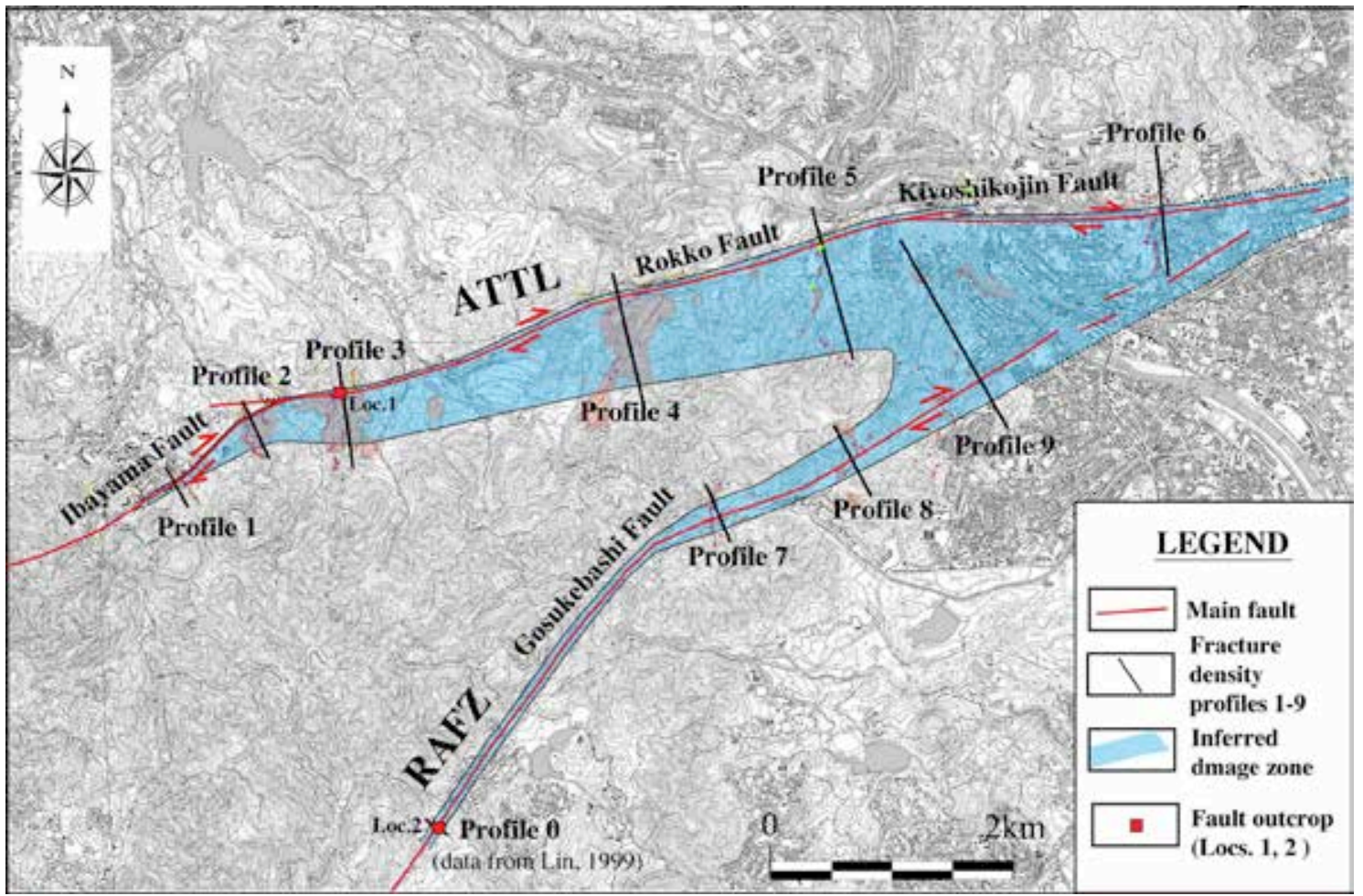

510 Figure 7. Topographic map showing the distribution of damage zones (blue area) within

511 the ATTL and RAFZ (base map is a 1:25,000 topographic map published by the

512 Geospatial Institution Authority of Japan). Profiles 1-9 correspond to those shown in

513 Figure 3. Data for Profile 0 are from Lin (1999).

514 

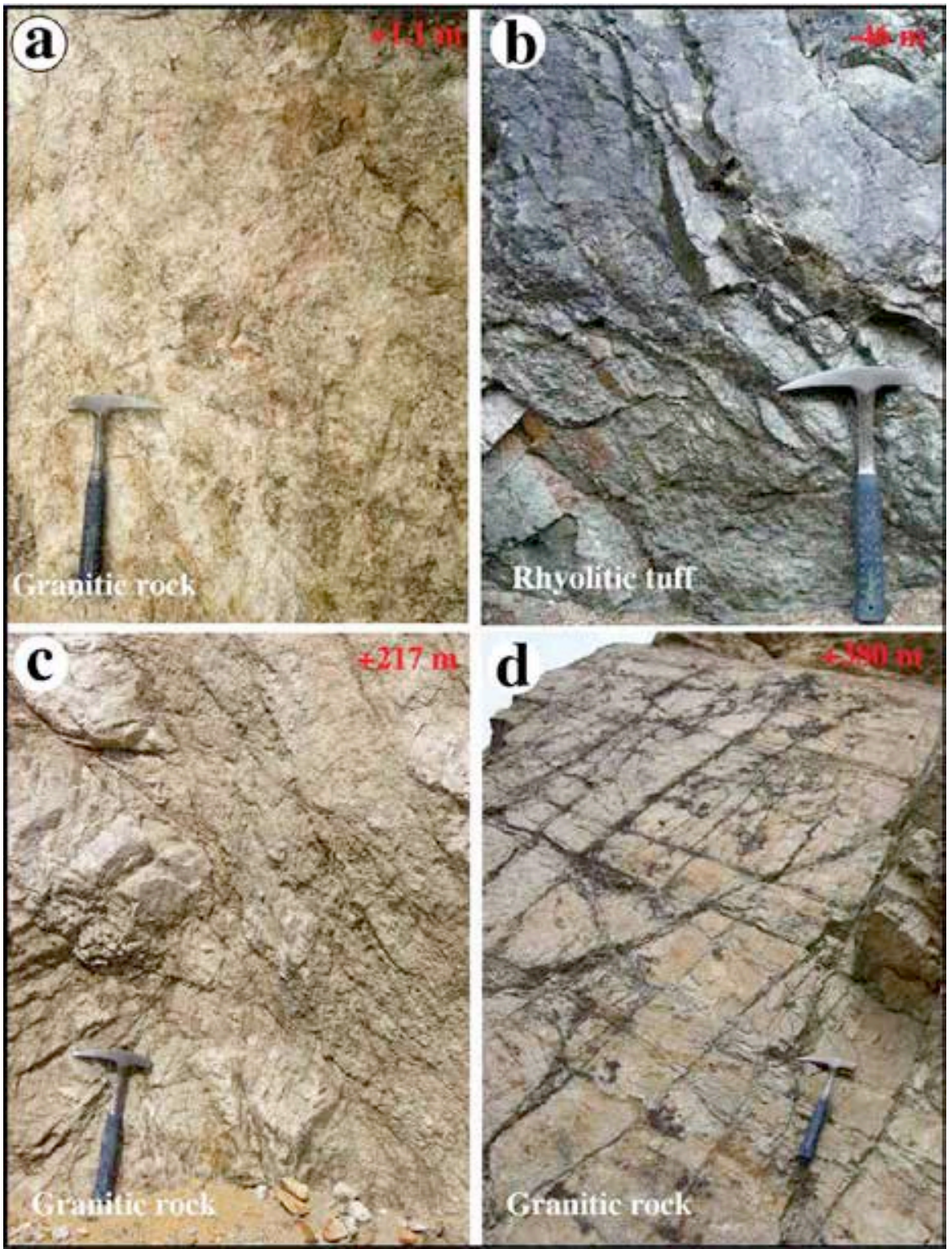

Figure 8. Photographs of the damage zone along the Rokko Fault. (a) Outcrop located $1.1 \mathrm{~m}$ from the main fault, within strongly deformed and weathered granitic rocks. (b) Outcrop located $46 \mathrm{~m}$ from the main fault, within rhyolitic tuff. (c-d) Damage zones at $217 \mathrm{~m} \mathrm{(c)}$ and $380 \mathrm{~m}(\mathrm{~d})$ from the main fault, within granitic rocks. Note that the fracture density decreases with increasing distance from the main fault. The numbers at top right in each panel indicate the distance from the main fault (negative numbers indicate the southeast side, within granitic rock; positive numbers indicate the northwest side, within rhyolitic tuff). (a) Grid interval is $1 \mathrm{~m}$ for scale. The signs (- and + ) indicate the northern and southern side from the main fault, respectively. 

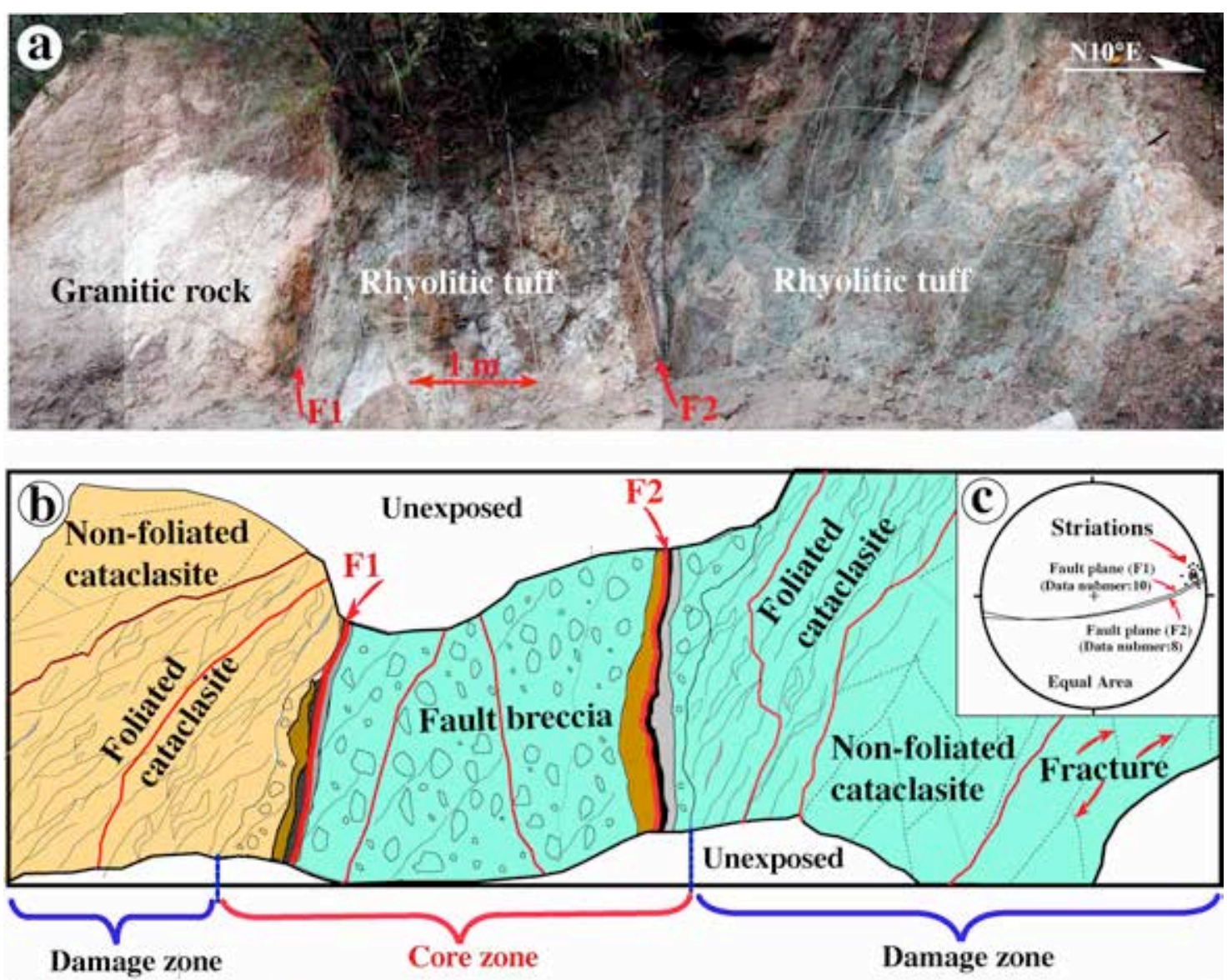

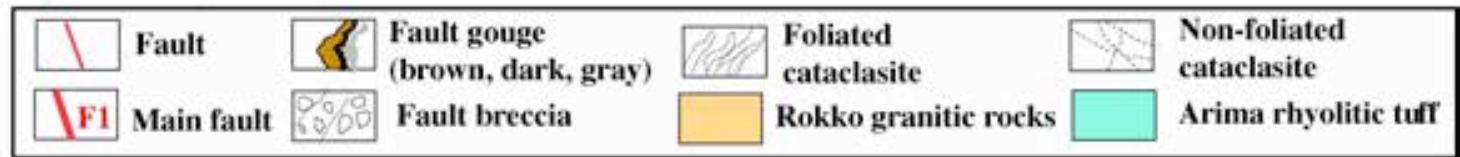

Figure 9. Photograph (a) and accompanying sketch (b) of the Rokko Fault (ATTL) and (c) striations at Loc. 1. See Figure 3 for the location. The core zone is composed of unconsolidated fault gouge and fault breccia, and the damage zones consist of foliated and non-foliated cataclasites that bound the core zone on both sides. Striations on the fault planes (F1 and F2) indicate mainly strike-slip movement. Loc.1: main outcrop described in the text. (a) Grid interval is $1 \mathrm{~m}$ for scale. 


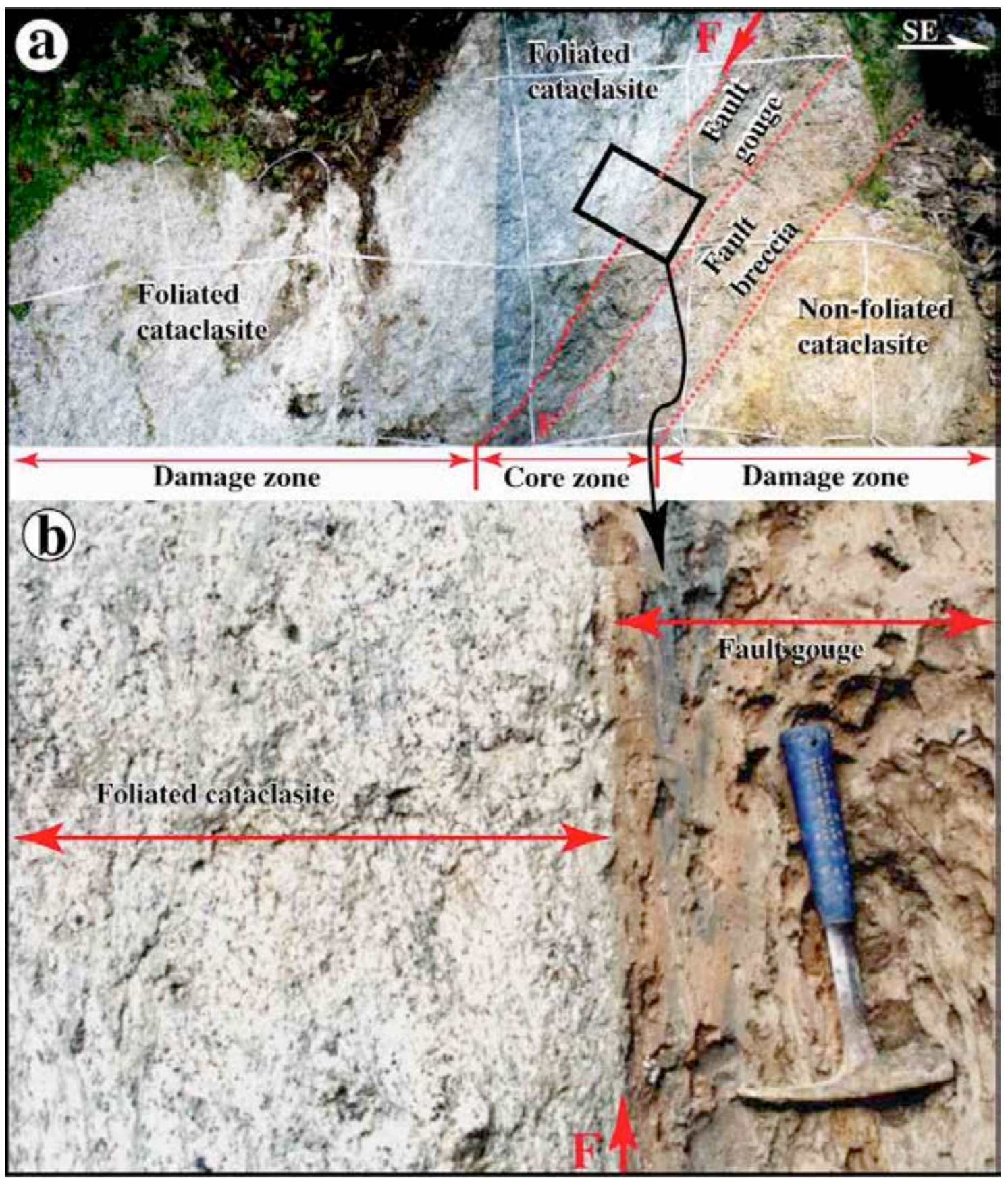

Figure 10. Photographs of the Kosukebashi Fault at Loc. 2. See Figure 3 for the location. (a) Overview of the outcrop. (b) Close-up view of (a). The core zone is composed of unconsolidated fault gouge and fault breccia, and the damage zones consist of foliated cataclasite on the northwest side of the fault, and non-foliated cataclasite on the southeast side. The fault gouge occurs in a zone that is $20-50 \mathrm{~cm}$ wide, and consists of layers that are brown, gray, and brownish gray in color. F: main fault plane. 

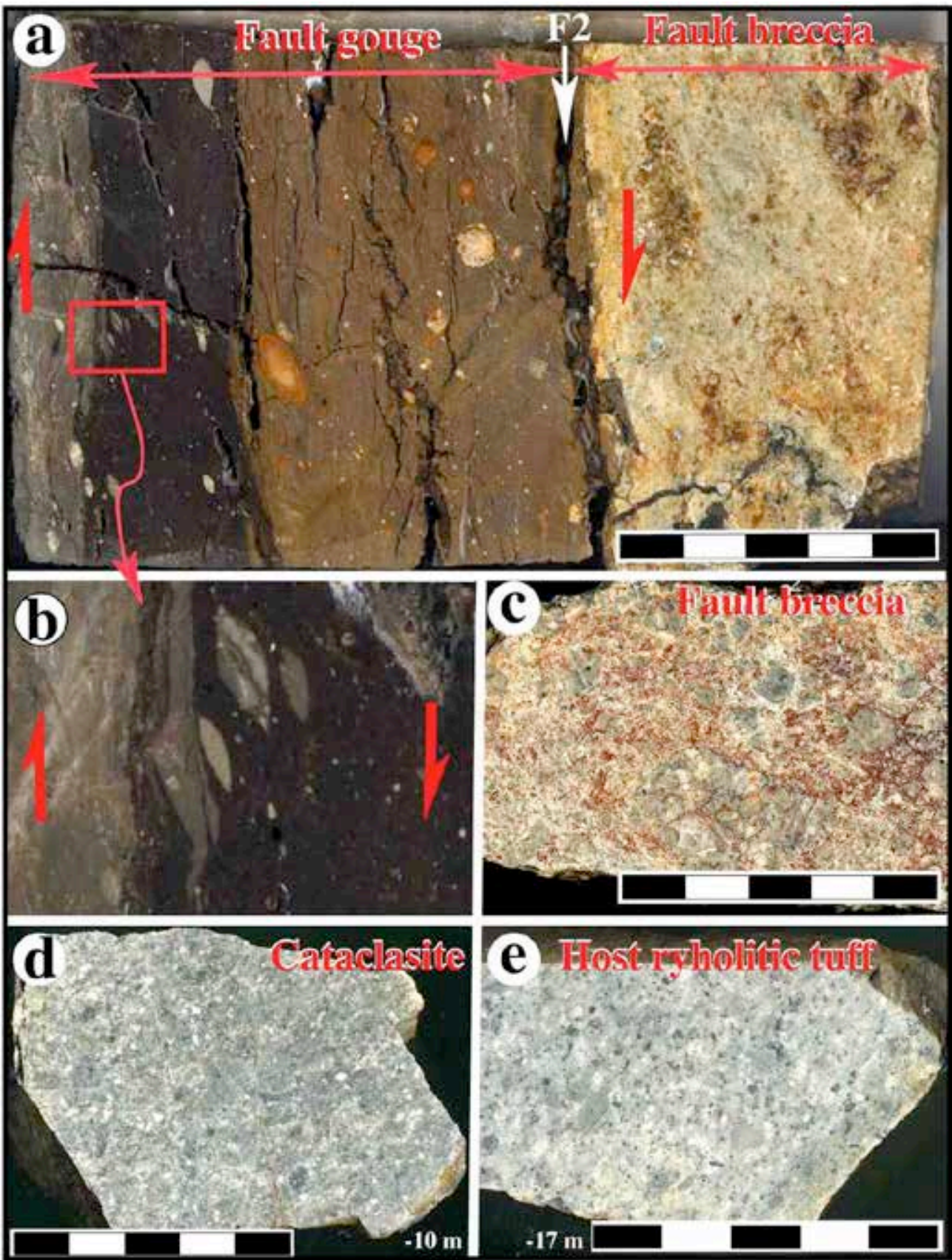

Figure 11. Photographs of polished hand samples from the Rokko Fault. (a) X-Z section of fault gouge and fault breccia from Loc. 1. (b) Close-up view of (a). The fault gouge is composed of gray, black, and brownish-gray layers. The fault gouge contains an asymmetric fabric that indicates a predominately dextral sense of movement. (c)

549 Fault breccia composed of angular to sub-angular fragments of various sizes $(\sim 0.1 \mathrm{~mm}$ 550 to $1 \mathrm{~cm}$ ). (d) Cataclasite developed from rhyolitic tuff at $10 \mathrm{~m}$ from the main fault. (e)

551 Undeformed rhyolitic tuff at $17 \mathrm{~m}$ from the main fault. 


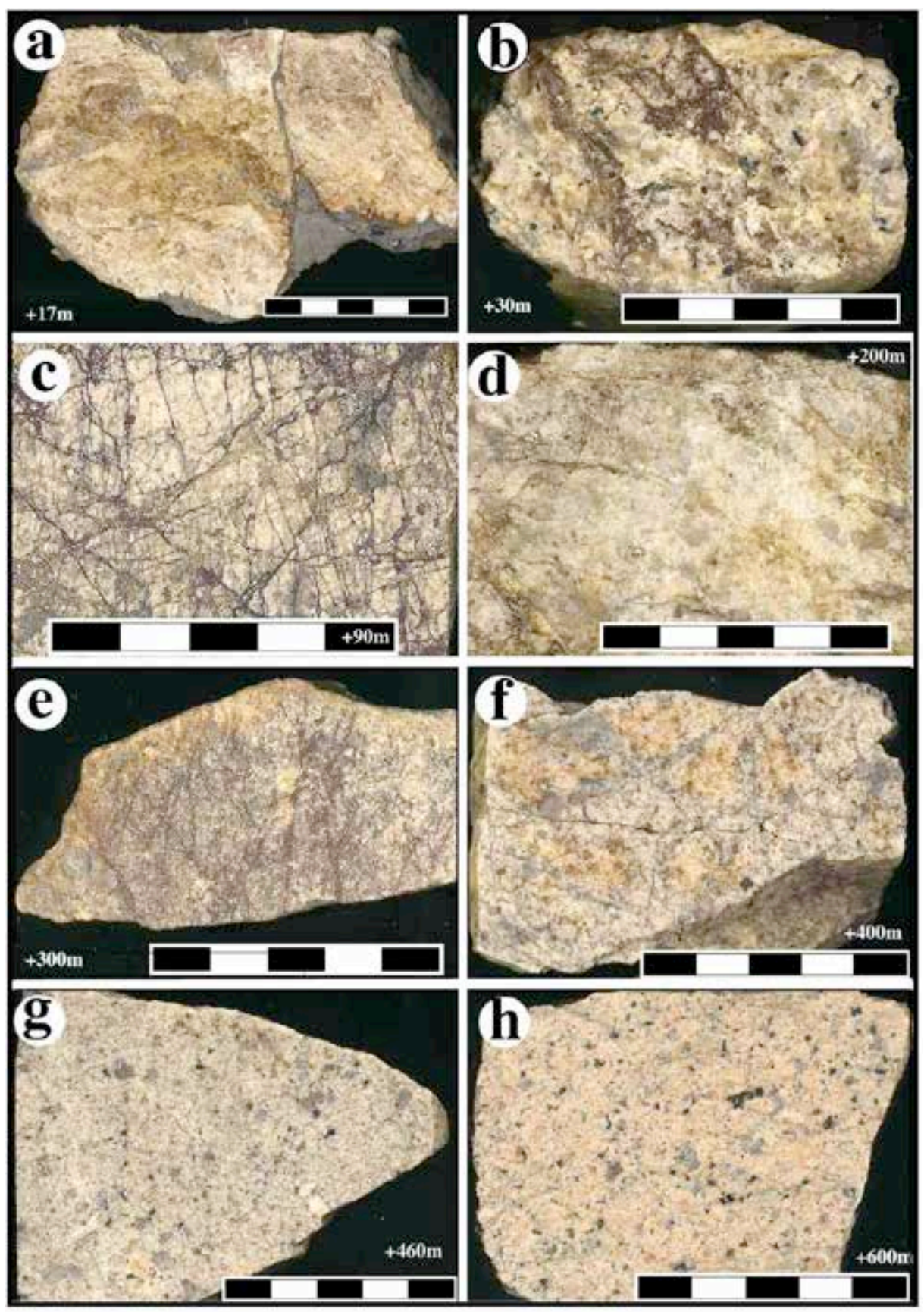

Figure 12. Photographs of polished hand samples from the Rokko Fault. (a-e) Granitic cataclasite from locations at $17 \mathrm{~m} \mathrm{(a),} 30 \mathrm{~m}$ (b), $90 \mathrm{~m}$ (c), $200 \mathrm{~m}$ (d), and $300 \mathrm{~m}$ (e) from the main fault. The granitic rocks are strongly deformed and partially brecciated. (f-g)

558 Weakly deformed granitic rocks from locations at $400 \mathrm{~m}(\mathrm{f})$ and $460 \mathrm{~m}(\mathrm{~g})$ from the main fault. Note that cracks are apparent in the rock. (h) Undeformed granitic rock from 560 a location at $600 \mathrm{~m}$ from the main fault. 

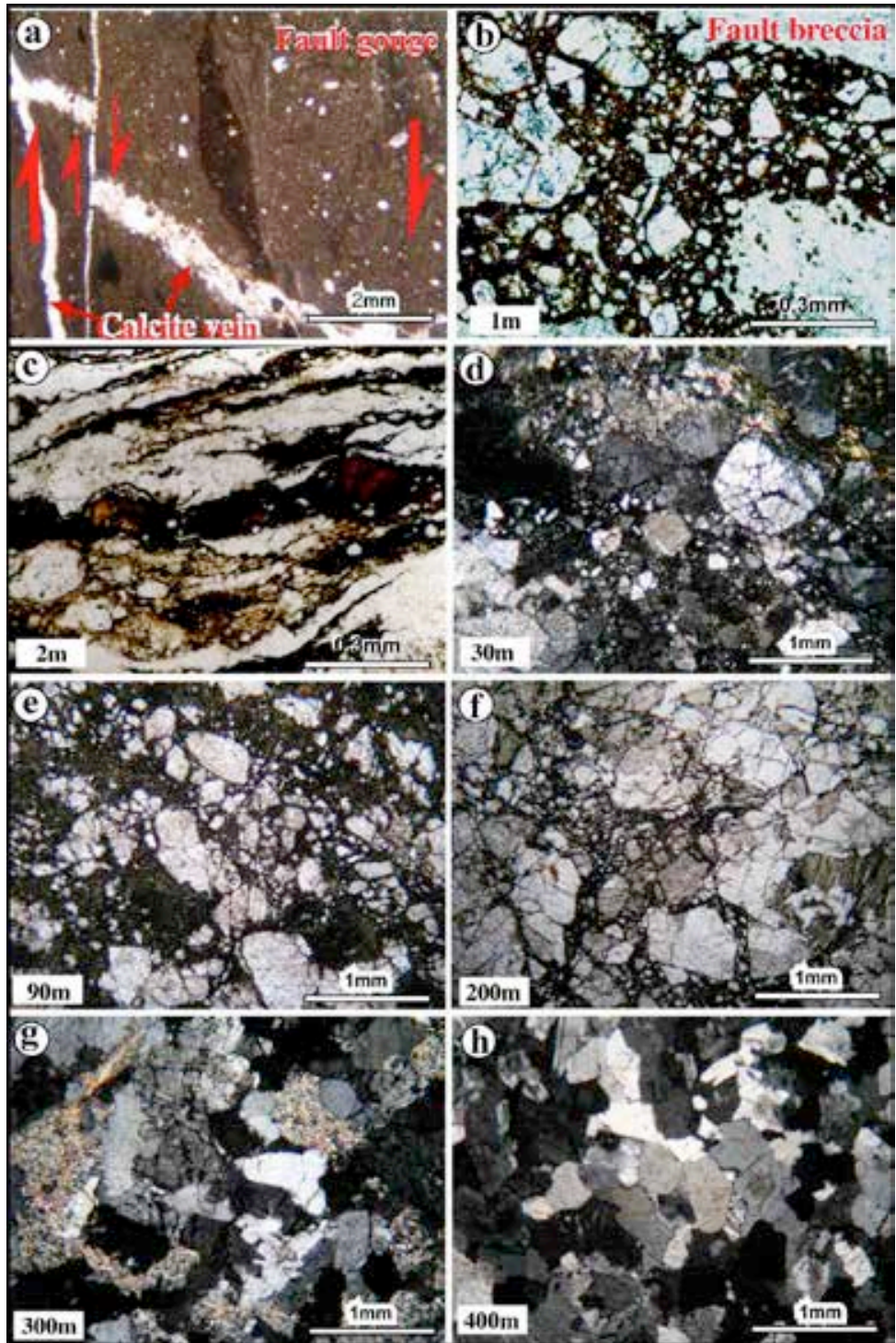

562

Figure 13. Photomicrographs showing the textures of the fault core zone and the damage zone. (a) The fault gouge is characterized by an asymmetric fabric and offset calcite veins (Loc. 1) that indicate dextral displacement (red arrows). (b) Fault breccia comprising angular microbreccia clasts in a fine-grained matrix (Loc. 1). (c) Foliated cataclasite is characterized by rock fragments and aggregations of fine-grained material with a preferred orientation, colored layers, and cracks ( $2 \mathrm{~m}$ from the main fault of the Gosukebashi Fault, at Loc. 2). (d-g) Non-foliated cataclasites derived from granitic rocks at sites located $30 \mathrm{~m}(\mathrm{~d}), 90 \mathrm{~m}(\mathrm{e}), 200 \mathrm{~m}(\mathrm{f})$, and $300 \mathrm{~m}(\mathrm{~g})$ from the main fault of

571 the ATTL. Note that the granitic rocks are strongly deformed and partially brecciated.

572 (h) Weakly deformed granitic rock at $600 \mathrm{~m}$ from the main fault of the ATTL. (a-c, e, f)

573 Plane-polarized light, $(\mathrm{d}, \mathrm{g}-\mathrm{h})$ cross-polarized light. 


\section{(a)}

\section{Compression} fault jog
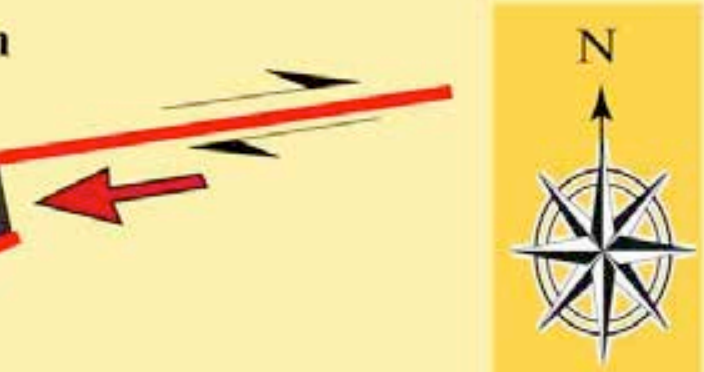

Compressive
pressure
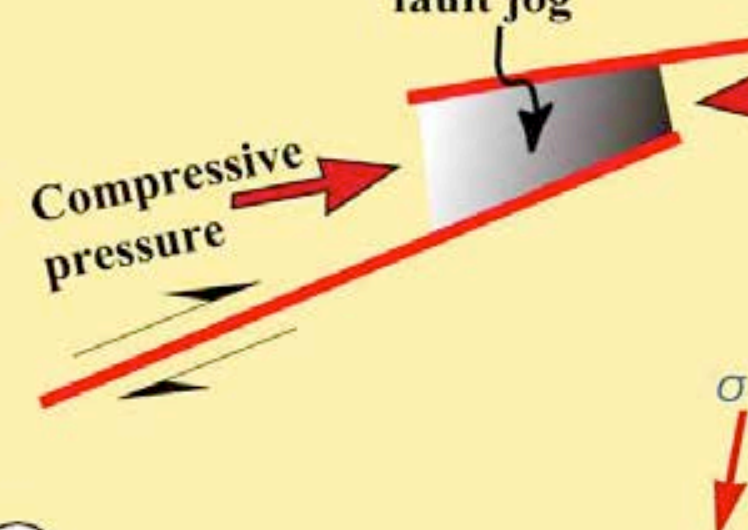

(b)
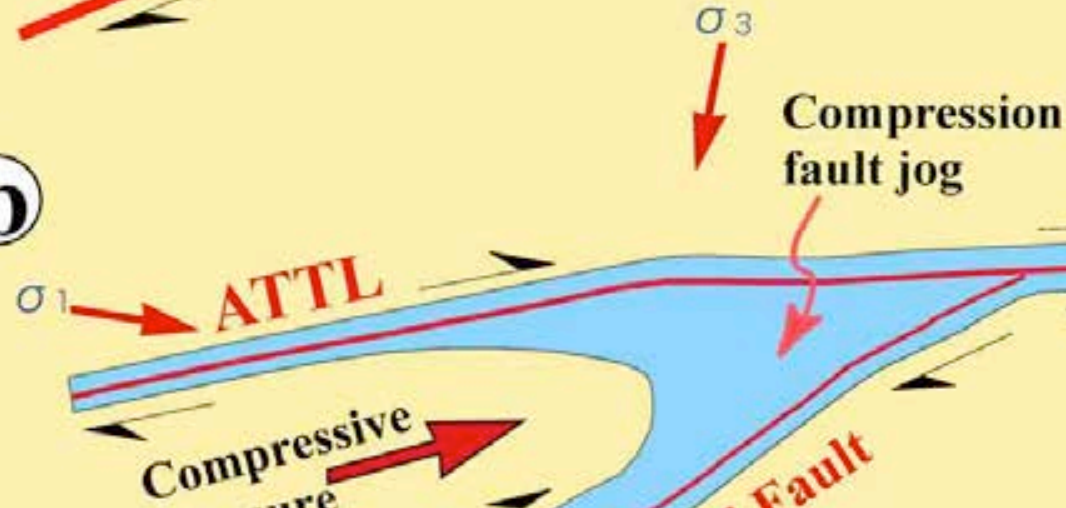
pressure

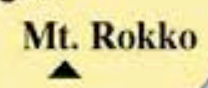

\section{fault jog}

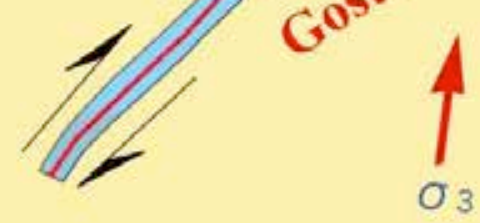

Damage zone

576 Figure 14. Schematic model of a compressional jog within a strike-slip fault zone (a) and the distribution of damage zones along the ATTL and RAFZ (b). Note that a wide damage zone is developed in the compression jog between the left-stepping strike-slip faults. See the text for details. 